\title{
HYBRID WARS OF OUR TIME
}

\author{
(C) Andrey Yu. Cherepanov
}

\author{
Branch of the Air Force Academy named after Prof. Zhukovsky and Yu.A. Gagarin, \\ Syzran, Samara region, Russian Federation \\ cherepanov-308@mail.ru
}

The main goal of the article is to form an idea of modern hybrid warfare. The historical forms of hybridity and their transformation at the present stage are considered. The goals of hybrid wars, the reason for their occurrence, as well as the main participants in these conflicts are identified. Thus, in spite of the fact that it is obvious that hybridity has always been inherent in wars, modern hybrid wars have reached a completely new level. Initially, hybridity acted as an auxiliary function of classic wars. Now it is an absolutely independent system that unites interrelated elements, the work of which is aimed at achieving one goal. One of the main forms of modern hybrid warfare is the use of hidden, not always armed formations, the purpose of which is to destroy the stability of the existing government.

Key words: hybrid war, protest, irregular formations, the aggressor country, the destruction of the political system.

\section{[А.Ю. Черепанов Гибридные войны современности]}

Основная цель статьи - формирование представления о современной гибридной войне. Рассматриваются исторические формы гибридности и их трансформация на современном этапе. Выявляются цели гибридных войн, причина их возникновения, а также основные участники данных конфрликтов. Показано, что гибридность была присуща войнам всегда, современные гибридные войны вышли на совершенно новый уровень. Первоначально гибридность выступала как вспомогательная функция классических войн, сейчас это абсолютно самостоятельная система, объединяющая взаимосвязанные элементы, работа которых направлена на достижение одной цели. Одной из основных фрорм ведения современной гибридной войны является применение скрытых не всегда вооруженных формирований, целью которых является уничтожение стабильности существующей власти.

Ключевые слова: гибридная война, протест, нерегулярные формирования, страна агрессор, уничтожение политического строя.

Andrey Yu. Cherepanov - Senior Lecturer, Branch of the Air Force Academy named after Prof. Zhukovsky and Yu.A. Gagarin, Syzran, Samara region, Russian Federation.

Черепанов Андрей Юрьевич - старший преподаватель, филиал Военного учебно-научного чентра Военно-воздушных сил «Военно-воздушная академия им. проф. Н.Е. Жуковского и Ю.А. Гагарина»,.. Сызрань, Самарская область, Российская Федерация.

War has always been an extreme form of solving political problems by violent means [4, p. 55-56]. War has almost always been a direct armed confrontation between states. Along with the use of various types of weapons, non-standard forms of influence on the enemy that were available at the time were always used: information, psychological, economic and other actions. This combination of unconventional forms of influence on the enemy and traditional armed means can be considered as a manifestation of the hybrid nature of warfare. Any war, in our opinion, is a hybrid war, because since the ancient times, non-standard components of the military counteraction are the satellites of almost all wars. Information psychological influence on the enemy in ancient times was limited to verbal 
technologies, i.e. technologies of information transmission by means of speech (oral or written). They were complemented by visual means of intimidation, such as intimidating drawings and signs. The advent of the printing expanded the possibilities of influencing the enemy. Leaflets, posters, and newspapers have become indispensable carriers of disinformation and propaganda. The advent of radio and television, and especially the Internet, brought the information psychological component of warfare to the highest level.

The economic impact on the enemy has almost always taken two forms - social and financial. The social form includes ways of undermining the economic stability of the state by fomenting local discontent, which arises when large-scale strikes and work stoppages are organized and financed by outside forces. The social component also includes informational impact on residents, the purpose of which is to reduce confidence in the economic institutions of the country. Financial forms of economic warfare include various financial methods (embargoes, sanctions, etc.), aimed at artificially reducing the economic stability of the country [3].

Thus, the blending of the various elements used to achieve the primary objective of capturing the enemy state suggests that hybridity has always been inherent in wars. Such a viewpoint is held by D.I. Kolesnikov, A.M. Krivenko, who point out that hybrid warfare is not a manifestation of the new times only [5, p. 113]. The hybrid component of wars before the advent of nuclear weapons was of an auxiliary importance. Armed combat, requiring enormous human and technical resources, has always come first. V. I. Slipchenko writes that "... the most important essence of any war is an armed struggle, since weapons were the main and only means of violence in the wars of the past, remain in the present and probably will remain in the future" [11]. Such wars are commonly referred to as classical or wars by K. Clausewitz.

In the middle of the twentieth century, classic warfare, with its front lines, rear lines, and direct armed confrontations, began to recede into the background. The impetus for this transformation was the appearance of weapons of mass destruction. It was its emergence that led to the reformatting of classic wars in which direct armed confrontation was a priority. Nuclear weapons were a certain apogee of the existing arsenal of weapons, they surpassed it many times over in their destructive characteristics. The use of weapons of mass destruction would lead to the self-destruction of the entire civilized world. Understanding this factor presented certain states with a difficult choice, in which the desire to seize the territory of an independent state could border on the self-destruction of the state itself. Despite this, the logic of any war remains the same: destruction of the enemy by any means except mutual destruction [5, p. 114]. This has led to the fact that "...in order to prevent the death of mankind through the use of weapons of mass destruction, the warring parties are forced to resort to a certain flexibility and selectivity. In this regard, "hybrid wars become the most unpredictable, but are not driven to extremes for fear of mutual annihilation" [5, p. 114]. It follows that past and present wars have one important difference: Open warfare, which was a fundamental factor in the wars of the past, has been relegated to the background due to the advent of weapons of mass destruction. Its place is taken by "...something more subtle, selective, concrete and sophisticated". It is in this concept that the idea of "hybrid warfare" fits in" [13, p. 127]. Hybridity, as noted above, has always been inherent in wars, but with the advent of nuclear weapons its forms and methods, i.e. the technology of its implementation, began to change, develop and improve. This leads to the conclusion that "...a combination of traditional and hybrid methods is already a feature of armed conflicts. At the same time, while the latter can be used without overt use of military force, the classic warfare without hybrid warfare cannot be" [10]. 
Many scholars of war believe that along with economic, informational and psychological forms of hybrid warfare, the arsenal of hybrid wars also includes military measures of a covert nature: "...initiation of 'hot spots' along the perimeter of national borders and within the country, activation of the 'fifth column', terrorist acts [10]. In this case hybrid warfare becomes a symbiosis of regular and irregular forms of warfare [6, p. 129]. In conducting such a war there is a shift towards using the "civilian component", the irregular formations of various kinds, that is, the capture of the enemy state takes place without the use of regular armed units, which once again confirms the fact that the classic war with its direct engagements takes second place.

At first glance, the absence of regular armed forces in the fighting suggests that wars have become more humane, but the relatively short history of modern hybrid warfare suggests quite the opposite. Hybrid warfare does not involve the use of moral, ethical and legal norms, the laws of war become optional. For an aggressor country, the main thing is the goal, and the means of conducting a hybrid war can be very different. Unlike classical warfare, the beginning of hybrid warfare is almost impossible to determine and is never officially declared. The aggressor country, trying to conceal its involvement in this conflict, acts as a third force, which at first sight has absolutely no interest in conflicts on the territory of the invaded country. In that case, minimizing the risks of open hostilities leads to the use of various, not always armed elements in a given conflict. The main impact forces in this case are various protest organizations used secretly, destructive opposition, criminal and extremist groups, receiving support in the form of financial, informational and other assistance from the outside governing force. In this regard, the third force in this conflict is able to fight "in secret" and achieve the required military-political results without revealing itself and, most importantly, without using regular armed units [2].

The application of protest potential almost always begins with the information processing of the civilian population. The main target of the attack is the immature minds of young people of the country, who in contrast to older age groups have absolutely different values, life principles, heightened emotionality and to some extent more radical character. Manipulation of them, incitement of national, religious, political instability can lead to protest sentiments not only among young people, but also among the older generation. An unorganized, chaotically arising protest is doomed to failure, so to destroy the political system of the victim state, the protest must have specific goals, objectives and a leadership that receives funding from abroad.

Protest actions "properly" controlled from the outside are turning into "color" revolutions aimed at destroying the political system of the victim country. The model underlying such revolutions is the same: "creating a protest movement, turning it into a political crowd and directing its aggression at the current government in order to force it to voluntarily step down from government positions and give up governing the country" [9, p. 27].

In order to bring people to the streets, protest movements must be led by counterelites, who are ready to accept any assistance (moral, material, etc.), both from external and internal sources [7, p. 32]. Various independent foundations, non-governmental institutions and organizations, are the "labor force" generating "color" revolutions [8, p. 23]. Another controlled, and thus externally financed force can be that part of the population which for various reasons is ready to do harm to their country - the so-called "fifth column". The politicians dissatisfied with the existing power, ready to sell anyone for money, a separate part of the country's citizens who are always dissatisfied with everything, gullible "useful idiots", the dregs of society and representatives of the criminal world ready to tear anyone apart at the command "Attack!" [12]. 
If we add to this set of protesting forces the irregular armed groups used in covert military operations to destroy the ruling elites, as well as those used to ignite pockets of instability on the territory of the victim country, we get a grim cocktail, the use of which will lead to irreversible consequences. Stability could be undermined by the introduction of regular armed groups under the pretext of saving the state system, which would lead to a final change of power in the country being seized. The use of regular formations is completely optional: Any aggressor country that does not want to advertise its involvement will do so only as a last resort. Therefore, in hybrid warfare "...an attacker does not use a classic military invasion, but instead destroys his opponent using a series of covert operations, sabotage, cyber warfare, and supporting insurgents operating in the enemy's territory. In addition, there may be no military action at all, and the hybrid warfare will take place in peacetime" [1, p. 88].

Thus, while hybridity has always been inherent in warfare, modern hybrid warfare has reached a whole new level. Originally, hybridism acted as an auxiliary function of classical warfare; now it is a completely independent system, integrating interrelated elements that work toward a single goal. One of the main forms of modern hybrid warfare is the use of covert, not always armed formations whose purpose is to destroy the stability of the existing power.

\section{Лumepamypa}

1. Бугорская E.Н., Емельянова О.В. "Гибридная война" как новый тип войны в 21 веке. В сборнике: Актуальные проблемы международных отношений в условиях формирования мультиполярного мира. Сборник научных статей 8-й Международной научно-практической конференции. 2019. С. 88-90.

2. Данюк Н. Филимонов Г. «Гибридная война»: интерпретации и реальность. [Электронный ресурc] URL: http://www.svom.info/entry/740-gibridnaya-vojnainterpretacii-i-realnost/. Дата обращения: 16.07.2021.

3. Иванов E. Экономические аспекты гибридной (холодной) войны. [Электронный pecypc] URL: https://www.geopolitica.ru/article/ekonomicheskie-aspekty-gibridnoyholodnoy-voyny. Дата обращения: 02.07.2021.

4. Клаузевиц К. О войне: Пер. с нем. М.: Издательская корпорация "Логос"; Международная академическая издательская компания "Наука", 1994. 448 с.

5. Колесников Д.И., Кривенко А.М. К проблеме сущности и специфики гибридной войны. военный академический журнал. 2020. № 1 (25). С. 110-114.

6. Комлева Н.А. Гибридная война: сущность и специфика. Известия Уральского федерального университета. Серия 3: Общественные науки. 2017. Т. 12. № 3 (167). С. 128-137.

7. Лейн Д. «Цветная» революция как политический феномен // Социология: теория, методы, маркетинг. 2010. № 1. С. 16-38.

8. Макаревич Э.Ф., Карпухин О.И. Технологии «цветных революций» // Социально-гуманитарные знания. 2014. № 3. С. 22-37.

9. Манойло А.В. Украина - генеральная репетиция // Стратегия России. №4(136). 2015. C. 23-32.

10. Мурат Тулеев. Гибридные методы войны: современные реалии и перспективы. [Электронный ресурс] URL: https://prudentsolutionsanalitika.org/2018/03/05/гибридные-методы-войны-современные-р/. Дата обращения: 25.06.2021. 
11. Слипченко В.И. Войны шестого поколения. Оружие и военное искусство будущего. [Электронный ресурc] URL: http://www.libros.am/book/read/id/52435/slug/vojjnyshestogo-pokoleniya-oruzhie-i-voennoe-iskusstvo-budushhego. Дата обращения: 28.01.2018.

12. Что такое «цветные революции» или немного о конспирологии и пропаганде. [Электронный ресурс] URL:

https://zen.yandex.ru/media/id/5bc46560dca03c00aba381e5/chto-takoe-cvetnyerevoliucii-ili-nemnogo-o-konspirologii-i-propagande-5c5eb11736c2d700aebf61da. Дата обращения: 12.05.2020.

13. Щеглов А.Ф. Гибридная война: мифы и реалии. В сборнике: Омские социально-гуманитарные чтения-2017. Материалы X Международной научнопрактической конференции. 2017. С. 126-129.

\section{References}

1. Bugorskaya Ye.N., Yemelyanova O.V. "Gibridnaya voyna" kak novyy tip voyny v 21 ve-ke. $V$ sbornike: Aktualnyye problemy mezhdunarodnykh otnosheniy $v$ usloviyakh formirovaniya multipolyarnogo mira. Sbornik nauchnykh statey 8-y Mezhdunarodnoy nauchno-prakticheskoy konferentsii ["Hybrid war" as a new type of war in the 21st century. In the collection: Actual problems of international relations in the formation of a multipolar world. Collection of scientific articles of the 8th International Scientific and Practical Conference]. 2019. pp. 88-90 (in Russian).

2. Danyuk N. Filimonov G. «Gibridnaya voyna»: interpretatsii i realnost ["Hybrid War": Interpretations and Reality]. Available at: http://www.svom.info/entry/740-gibridnayavojna-interpretacii-i-realnost/ (accessed: 16 July 2021) (in Russian).

3. Ivanov Ye. Ekonomicheskiye aspekty gibridnoy (kholodnoy) voyny [Economic aspects of the hybrid (cold) war]. Available at: https://www.geopolitica.ru/article/ekonomicheskie-aspekty-gibridnoy-holodnoyvoyny (accessed: 02 July 2021) (in Russian).

4. Klauzevits K. O voyne [About war]. Moscow: Izdatelskaya korporatsiya "Logos"; Mezhdunarodnaya akademicheskaya izdatelskaya kompaniya "Nauka". 1994. 448 p. (in Russian).

5. Kolesnikov D.I., Krivenko A.M. K probleme sushchnosti i spetsifiki gibridnoy voyny. Voyennyy akademicheskiy zhurnal [On the problem of the essence and specificity of hybrid warfare. Military academic journal]. 2020. No. 1 (25). pp. 110-114 (in Russian).

6. Komleva N.A. Gibridnaya voyna: sushchnost i spetsifika. Izvestiya Uralskogo federal'nogo universiteta. Seriya 3: Obshchestvennyye nauki [Hybrid war: essence and specificity. Bulletin of Ural Federal University. Series 3: Social Sciences]. 2017. V. 12. No. 3 (167). pp. 128-137 (in Russian).

7. Leyn D. «Tsvetnaya» revolyutsiya kak politicheskiy fenomen ["Colour" revolution as a political phenomenon]. Sotsiologiya: teoriya, metody, marketing. 2010. No. 1. pp. 16-38 (in Russian).

8. Makarevich E.F., Karpukhin O.I. Tekhnologii «tsvetnykh revolyutsiy» [Technologies of "color revolutions"]. Sotsialno-gumanitarnyye znaniya. 2014. No. 3. pp. 22-37 (in Russian).

9. Manoylo A.V. Ukraina - generalnaya repetitsiya [Ukraine is the dress rehearsal]. Strategiya Rossii. No. 4(136). 2015. pp. 23-32 (in Russian). 
10. Murat Tuleyev. Gibridnyye metody voyny: sovremennyye realii i perspektivy [Hybrid methods of war: modern realities and perspectives]. Available at: https://prudentsolutions-analitika.org/2018/03/05/gibridnyye-metody-voynysovremennyye-r/ (accessed: 25 June 2021) (in Russian).

11. Slipchenko V.I. Voyny shestogo pokoleniya. Oruzhiye i voyennoye iskusstvo budushchego [Sixth generation wars. Weapons and martial arts of the future]. Available at: http://www.libros.am/book/read/id/52435/slug/vojjny-shestogo-pokoleniyaoruzhie-i-voennoe-iskusstvo-budushhego (accessed: 28 January 2018) (in Russian).

12. Chto takoye «tsvetnyye revolyutsii» ili nemnogo o konspirologii i propaganda [What are "color revolutions" or a little about conspiracy and propaganda]. Available at: https://zen.yandex.ru/media/id/5bc46560dca03c00aba381e5/chto-takoe-cvetnyerevoliucii-ili-nemnogo-o-konspirologii-i-propagande-5c5eb11736c2d700aebf61da (accessed: 12 May 2020) (in Russian).

13. Shcheglov A.F. Gibridnaya voyna: mify i realii. V sbornike: Omskiye sotsialnogumanitarnyye chteniya-2017. Materialy X Mezhdunarodnoy nauchnoprakticheskoy konferentsii [Hybrid war: myths and realities. In the collection: Omsk Social and Humanitarian Readings-2017. Materials of the the $10^{\text {th }}$ International Scientific and Practical Conference]. 2017. pp. 126-129 (in Russian). 